THE PARADOXES OF POSTERITY 



\section{THE PARADOXES}

OF POSTERITY

BENJAMIN HOFFMANN

Translated by Alan J. Singerman

THE PENNSYLVANIA STATE UNIVERSITY PRESS UNIVERSITY PARK, PENNSYLVANIA 
Library of Congress Cataloging-in-Publication Data

Names: Hoffmann, Benjamin, I985-author. | Singerman, Alan J., translator.

Title: The paradoxes of posterity / Benjamin Hoffmann ; translated by Alan J. Singerman.

Other titles: Paradoxes de la postérité. English

Description: University Park, Pennsylvania : The Pennsylvania State University Press, [2020] | First published in French in 2019 by Les éditions de Minuit under the title: Les paradoxes de la postérité | Includes bibliographical references and index.

Summary: "Examines the paradoxes inherent in the search for symbolic immortality, arguing that there is only one truly serious literary problem: the transmission of texts to posterity"-Provided by publisher.

Identifiers: LCCN 202001528I | ISBN 9780271087030 (cloth)

Subjects: LCSH: Authorship-Psychological aspects. Authorship-Philosophy. | Creation (Literary, artistic, etc.) | Mortality.

Classification: LCC PNi7i.P83 H63I3 2020 | DDC $808.02-\mathrm{dc} 23$

LC record available at https://lccn.loc.gov/20200I528I

Copyright (C) 2020 Benjamin Hoffmann All rights reserved

Printed in the United States of America

Published by The Pennsylvania State University Press, University Park, PA I6802-I003

First published by Les Éditions de Minuit Les paradoxes de la postérité (C) 2019 by Les Éditions de Minuit

7 rue Bernard-Palissy, 75006 Paris All rights reserved.

The Pennsylvania State University Press is a member of the Association of University Presses.

It is the policy of The Pennsylvania State University Press to use acid-free paper. Publications on uncoated stock satisfy the minimum requirements of American National Standard for Information Sciences-Permanence of Paper for Printed Library Material, ANSI Z39.48-I992. 
For my mother ................... 
